\title{
The Institutional Influence on the Location Strategies of Multinational Enterprises from Emerging Economies: Evidence from Ghina's Cross-border Mergers and Acquisitions
}

\author{
Peter J. Buckley, ${ }^{1,2}$ Pei Yu, ${ }^{3}$ Qing Liu, ${ }^{2}$ Surender Munjal, ${ }^{1}$ \\ and Pan Tao ${ }^{4}$ \\ ${ }^{1}$ University of Leeds, UK, ${ }^{2}$ University of International Business and Economics, China, ${ }^{3}$ Wuhan \\ University of Technology, China, and ${ }^{4}$ Shandong University of Finance and Economics, China
}

ABSTRACT This study investigates the institutional influence on the location strategies of Chinese cross-border mergers and acquisitions (M\&A) during the period 1985-2011 across 150 economies using Heckman's two-stage model. The results suggest that Chinese Multinational Enterprises (MNEs) are 'shortsighted' and show perverse behaviour towards host country risk when deciding on the location of host country and volume of investment undertaken through M\&As, which may damage the firm's long-term profitability.

KEYwORDs China's cross-border M\&A, EMNEs, institutions, location strategies

\section{INTRODUGTION}

The internationalisation of emerging multinational enterprises (EMNEs) and their anticipated future prospects are among the most significant recent changes in the global economy (Buckley, Munjal, Enderwick, \& Forsans, 2016a; Child \& Marinova, 2014; Kang \& Jiang, 2012;). In 2014, 132 EMNEs entered the Fortune Global 500 list and the outward foreign direct investment (OFDI) flow from emerging economies was US $\$ 759$ billion, equating to $39 \%$ of global foreign direct investment (FDI) flows (UNCTAD, 2014). Among these active EMNEs, Chinese MNEs have attracted the most attention, particularly since the implementation of the 'Go Global' policy in October 2000 (BEA, 2005; Deng, 2009; Zhang, Zhou, \& Ebbers, 2011). Scholars argue that Chinese MNEs are distinctive in certain respects, with implications for traditional international business (IB) theory (Alon, Child, Li, \& McIntyre, 2011; Boisot \& Meyer, 2008; Buckley, Clegg, Cross, Zheng, Voss, \& Liu, 
2007; Child \& Rodriguez, 2005; Gui \& Jiang, 2010; Ramaswamy, Yeung, \& Laforet, 2012).

Recently, the number and scale of cross-border mergers and acquisitions (M\&A) by Chinese MNEs have also started to accelerate (Sun, Peng, Ren, \& Yan, 2012) - a phenomenon which has attracted controversy in political circles but little academic scrutiny. One of the issues is the rationale underlying cross-border M\&As, as an increasing number of acquisitions are targeted at more advanced countries away from the home region (Economist, 2010); and the Chinese government's interventions still influence these firms (Luo, Xue, \& Han, 2010), which results in incautious investment decisions, in particular in the apparent lack of risk analysis. The Economist (2010) claims that, due to its opaque nature, China's important role as a foreign investor has been interpreted as a threat to countries in the west and sub-Saharan Africa (Bond, 2006; Brautigam, 2009). As a result, some M\&A deals proposed by Chinese MNEs have been stalled, e.g., Rio Tinto-Chinalco deal (BBC, 2009). In addition, Chinese MNEs are alleged to have low international business management ability and a lack of coherent overseas investment strategies (Wang, 2011). Scholars (e.g., Child \& Marinova, 2014) suggest that the empirical basis of these remarks on China's M\&As require much more careful analysis to investigate the motivations of Chinese cross-border M\&As, along with home and host country contexts to explain the location choices made by Chinese MNEs.

Scholars have carried out a great deal of research on the motives of China's OFDI and into the applicability of traditional frameworks of analysis (Buckley et al., 2007; Cheng \& Ma, 2010; Cheung \& Qian, 2009; Deng, 2004; Kolstad \& Wiig, 2012; Meyer, Estrin, Bhaumik, \& Peng, 2009; Sun et al., 2012). However, traditional investment motives, such as market size, labour costs, and resource endowments, originally developed in a western context, provide only a partial explanation of Chinese OFDI location strategies. Therefore, more work, taking into account the specific attributes of emerging economies, is called for (Cheng, 2014; Cuervo-Cazurra, Inkpen, Musacchio, \& Ramaswamy, 2014; Cui \& Jiang, 2010; Morck, Yeung, \& Zhou, 2008; Ramaswamy et al., 2012; Wang, Hong, Kafouros \& Boateng, 2012). The contribution of this paper therefore lies in exploring the institutional contexts both at home and in host countries to explain the motivation and location choices made by Chinese MNEs through cross-border M\&As.

The institution-based view is utilized as it is one of the most appropriate theoretical frameworks for probing business activities of MNEs from emerging economies (Hoskisson, Wright, Filatotchev, \& Peng, 2013). Unlike developed economies, where the 'rules of the game' are well developed (Peng, 2002), the institutional framework in emerging countries is often local context specific. Institutional constraints at home and in host countries (Dunning \& Lundan, 2008; Peng, Wang, \& Jiang, 2008) influence the strategic behaviour of EMNEs (Cui \& Jiang, 2010; Buckley, Munjal, Enderwick \& Forsans, 2016b). For instance, OFDI by Chinese MNEs requires approval by several Chinese authorities, and only those 
investment projects in line with the catalogue of 'encouraged' OFDI and in strict accord with government policies are allowed (Buckley et al., 2007; Pei \& Zheng, 2015; Zhang et al., 2011). Thus, it is argued that an institution-based view is needed to explain Chinese cross-border M\&As (Child \& Marinova, 2014; Meyer et al., 2009; Pajunen, 2008). A few empirical examinations of Chinese OFDI have taken into account institutional factors (e.g., Boisot \& Meyer, 2008; Buckley et al., 2007; Cheung \& Qian, 2009; Kolstad \& Wiig, 2012; Mork et al., 2008; Zhang et al., 2011), but they have not comprehensively modelled institutions in their empirical estimations, and thus did not obtain consistent results. Meyer et al. (2009) argue that macro-level institutions, such as country-level legal and political frameworks, have remained as mere 'background' and thus remain relatively unexplored.

The second contribution of this paper lies in a systematic and comprehensive examination of Chinese cross-border M\&As undertaken during the period 19852011. We argue that Chinese cross-border M\&As are worthy of a separate examination because they have become the main form of OFDI by Chinese MNEs. Previous studies on Chinese MNEs have largely focused on greenfield investments (Duanmu, 2012; Kang \& Jiang, 2012; Ramasamy et al., 2012), which, in fact, are likely to be determined by a separate set of factors (Bertrand \& Madariaga, 2002; Mata \& Portugal, 2000; Nicholson \& Salaber, 2013; Nocke \& Yeaple, 2008; Sun et al., 2012; Xia, Ma, Lu, \& Liu, 2013). Second, prior studies suffer from sample selection bias and use approved FDI data rather than actual investment or use qualitative case studies (Boateng, Qian, \& Tianle, 2008; Buckley et al., 2007; Deng, 2009; Hertenstein, Sutherland, \& Anderson, 2015; Rui \& Tip, 2008). Third, prior studies did not recognize that location choice and the volume of FDI are two different decisions. Thus, prior studies have potentially biased results. We account for these limitations by: first, creating a comprehensive dataset of completed crossborder M\&As; second, our dataset includes countries which do not host M\&As by Chinese MNEs; third, we use the Heckman two stage model, which examines the location choice decision in the first stage and the volume of investment in the second stage (Heckman, 1979).

In the next section, we describe our dataset on Chinese overseas M\&As. In the third section, we review the literature and formulate our hypotheses on location strategies of Chinese M\&As. The fourth section explains the econometric models, data and variables. Our results are discussed in the fifth section. The final section discusses management implications and concludes.

\section{GHINESE GROSS-BORDER M\&AS}

Our dataset is derived from Thomson Financial SDC Platinum database. It contains the most detailed record of global M\&A transactions, and therefore, is the world's most authoritative and widely used M\&A data source. We extracted all cases of China's cross-border M\&A transactions during January 1985 to December 2011. 


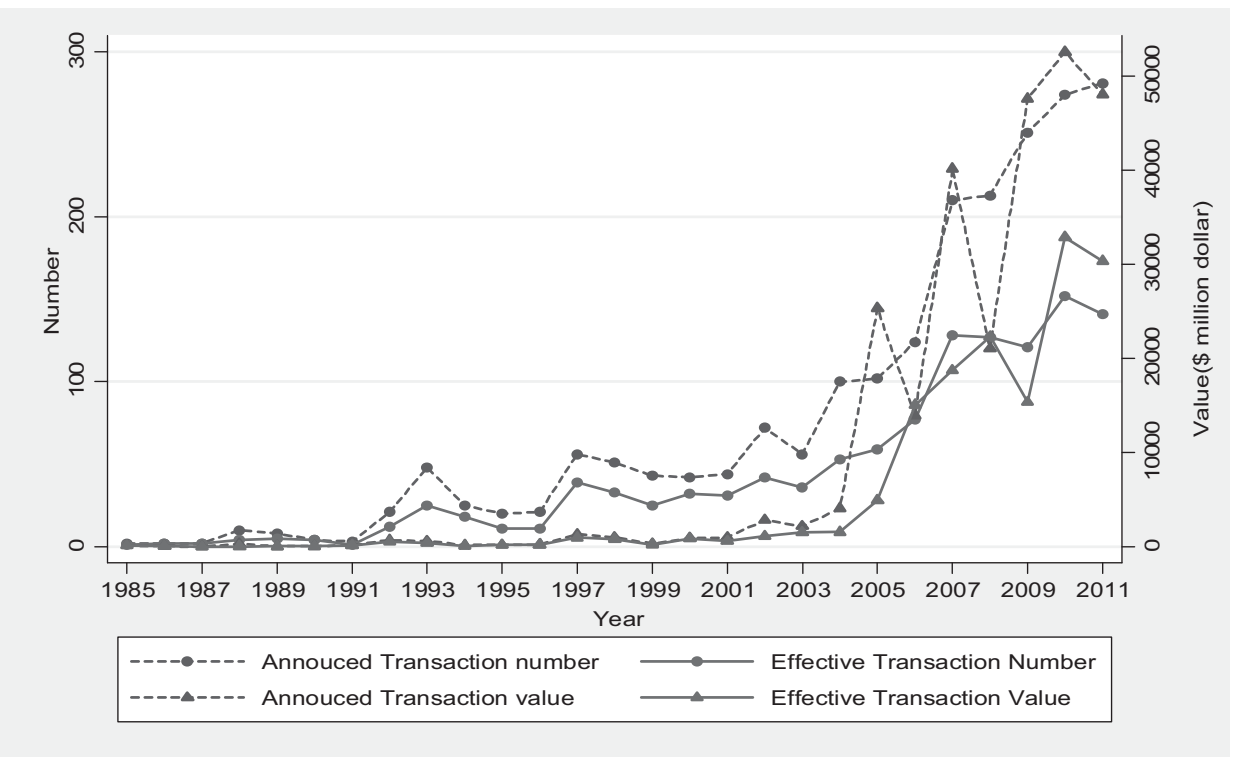

Figure 1. Chinese overseas M\&As from 1985 to 2011

Source: calculated by the authors from Thomson Financial SDC Platinum database.

During this period, 2085 acquisitions were announced and, of these, 1192 were actually completed.

China's overseas M\&As were rare before 1991 (see Figure 1). They began to increase steadily from 1992, largely due to the building of China's market economy after Deng Xiaoping's 'southern tour'. The real boom in overseas M\&As by Chinese MNEs occurred only after China's entry to the WTO in 2002 (Buckley et al., 2007). For instance, between 2002 and 2011, Chinese firms publicly announced their intention to undertake 1683 cross-border M\&As, amounting to US\$257.65 billion, of which 936 deals, amounting to US\$143.76 billion, were completed. In these 10 years, both announced and completed M\&As were four to five times more than the total number of M\&As announced and completed over the period 1985-2001. Our data also shows that the average transaction size has grown annually and the M\&As completion rate has stabilized at around $60 \%$.

Our data further show that Chinese MNEs have undertaken cross border M\&As in tax havens, such as the Cayman Islands, British Virgin Islands, Bermuda and the Isle of Man. These acquisitions were excluded because the primary motive of such transactions is tax planning and the final destination of the investment is not known. Table 1 shows the main target destinations for Chinese MNEs. Hong Kong is at the top of the list with 392 M\&As, followed by the US and Australia. Scholars (e.g., Peng et al., 2009) suggest that Chinese MNEs use Hong Kong as a strategic staging post for their further investments and also to develop financing channels for the parent firms. For these reasons we also exclude Hong Kong. 
Table 1. Main destinations of China's cross-border M\&A (1985-2011)

\begin{tabular}{|c|c|c|c|c|}
\hline \multirow[b]{2}{*}{ Destination } & \multicolumn{2}{|c|}{ No. of MËAs completed } & \multicolumn{2}{|c|}{ Volume of MEAAs completed (million US\$) } \\
\hline & No. of $M E A$ s & Ratio(\%) & Total MEAs volume & Average volume per $M E A$ \\
\hline Hong Kong & 392 & 32.89 & 21914.38 & 55.90 \\
\hline US & 149 & 12.50 & 15334.45 & 102.92 \\
\hline Australia & 126 & 10.57 & 17134.19 & 135.99 \\
\hline Singapore & 70 & 5.87 & 2140.27 & 30.58 \\
\hline Canada & 65 & 5.45 & 19361.15 & 297.86 \\
\hline Japan & 45 & 3.78 & 953.21 & 21.18 \\
\hline Germany & 26 & 2.18 & 176.39 & 6.78 \\
\hline UK & 21 & 1.76 & 7548.02 & 359.43 \\
\hline France & 20 & 1.68 & 4411.89 & 220.59 \\
\hline Taiwan & 18 & 1.51 & 68.00 & 3.78 \\
\hline South Korea & 17 & 1.43 & 1396.04 & 82.12 \\
\hline Indonesia & 15 & 1.26 & 1296.55 & 86.44 \\
\hline Netherlands & 15 & 1.26 & 882.09 & 58.81 \\
\hline Malaysia & 14 & 1.17 & 112.59 & 8.04 \\
\hline Italy & 13 & 1.09 & 775.46 & 59.65 \\
\hline Mongolia & 12 & 1.01 & 175.30 & 14.61 \\
\hline Brazil & 11 & 0.92 & 12689.28 & 1153.57 \\
\hline New Zealand & 9 & 0.76 & 153.00 & 17.00 \\
\hline
\end{tabular}

Source: calculated by the authors from Thomson Financial SDC Platinum database.

After these exclusions, our final sample totals 760 acquisitions hosted in 80 target countries.

It is interesting to note that developed countries in the West, e.g., US, Canada, Germany, UK, and France, are among top location choices for Chinese M\&As. This is a relatively new phenomenon - an outcome of the 'Go Global' policy which presents an intriguing case for the study of motivation of Chinese MNEs in seeking strategic assets available in these western economies, as compared to the previous strategy of investing in neighbouring countries for natural resource seeking purposes. Nicolas and Thomsen (2008) suggest that Chinese firms are investing in these European countries to seek brands and technology. These authors observed that some Chinese automobile firms have taken over small Italian firms in Turin to gain their technology and design capabilities. This is also likely to benefit the acquirer firms from the spillovers arising from the Moncalieri science and technology park in the vicinity.

The 'Go Global' policy has pushed Chinese MNEs to enhance their technological capabilities (Pei \& Zheng, 2015). In 2006, Chinese firms accounted for 2.8\% of total R\&D projects by foreign investors in Europe - rising from virtually zero in 2001 (Nicolas \& Thomsen, 2008). The latest 'Science, Technology and Industry Outlook' published by the OECD (2014) further suggests that the research intensity of Chinese firms has massively increased. China has edged out the European Union in terms of investment in R\&D with its R\&D to GDP ratio touching $2 \%$. 


\section{THEORETICAL BACKGROUND AND HYPOTHESES}

\section{Unlocking the Black Box of Chinese M\&As Location Strategies: An Institutional Framework}

Scholars argue that traditional theoretical frameworks of FDI have largely examined the location choice decisions in terms of transaction costs and the MNE's motivation in undertaking FDI (Yang et al., 2009). Consequently, the importance and the impact of institutions in the international business literature has remained 'thin' (Jackson \& Deeg, 2008: 540). However, the rise of the 'institution-based view' during the past decade has brought a new perspective to the explanation of MNEs' crossborder activities (Peng et al., 2009). It highlights the influence of the institutional framework embedded in national-level macro environments on the strategic choices available to the firm (Buckley, Forsans \& Munjal, 2012; Cui \& Jiang, 2010). Davis and North (1971: 6) initially defined the institutional framework as 'the set of fundamental political, social, and legal ground rules that establishes the basis of production, exchange, and distribution'. Thus, unlike the traditional frameworks of FDI, the institution-based view looks beyond the micro-level organization structure of the firm and its task environment (Peng et al., 2009; Wu \& Sia, 2002).

The institution-based constructs applied to FDI decisions originate from 'new institutional theory' which defines institutions as formal and informal 'rules of the game' (North, 1990: 3) codified in the form of 'regulative, normative, culturecognitive elements, that together with associated activities and resources, provide meaning and stability' (Scott, 1995: 56) to business organisations. Scholars (Child \& Marinova, 2014) suggest that institutional analysis of FDI decisions should be 'sensitive' to both home and host country contexts in order to systematically comprehend their implications on the firm investing into foreign countries. In the next two sections, we analyse the effect of the institutional framework at home and in host countries on the Chinese MNEs' decision to undertake cross-border M\&As.

\section{The Institutional Framework in the Home Country}

Some scholars predict that in a new era of Schumpeterian global competition and innovation, governments in emerging economies are pressured to support OFDI promotion policies that enhance firm's competitiveness and encourage innovation (Gammeltoft, 2012). In this respect, the Chinese government's influence on the internationalisation decisions of Chinese MNEs has been subject to close academic scrutiny. This is primarily because, unlike western countries and (also) other developing countries like India, the Chinese government's degree of involvement with the internationalisation decisions of Chinese MNEs is staggeringly high and with its state involvement based internationalisation model, Chinese MNEs have had a strong impact on the world economy. 
The Chinese government's policy direction on OFDI seems to have influenced Chinese MNEs' location choices and motivations of internationalisation (Quer et al., 2012; Richet, 2013; Yang et al., 2009). As discussed above, Chinese FDI follows the government's catalogue, which directs where and how FDI should be made. This directive is often driven by the political and strategic objectives of the Chinese government, e.g., its need to fuel the manufacturing base at home (Globerman \& Shapiro, 2009). Consequently, countries with large endowments of natural resources were preferred location choices of Chinese enterprises (Ramasamy et al., 2012). Investments by the 'big three' state owned enterprises, namely CNPG, GNOOC, and Sinopec, into African countries, in the 1990s, illustrate this argument (Cheung et al., 2012; Yao \& Wang, 2013).

Since the launch of the 'Go Global' policy, in 2002, Chinese OFDI policy has liberalized the sectors where FDI can be made by Chinese MNEs. There seems to be a thrust on strengthening of the technological and market competitiveness of Chinese MNEs. In October 2004, the National Development and Reform Commission (NDRG) and the China Export-Import Bank jointly issued a 'Policy Notice on the State's Encouragements of Key Foreign Investment Projects by Credit Support' to supplement the 'Go Global' policy. According to the joint notice, special financial assistance is available for supporting investments for: firstly, setting up overseas research and development centres which may utilize internationally advanced technologies, management experiences and professional talents; and secondly, cross-border M\&As which can improve the international competitiveness of Chinese enterprises, and accelerate the exploration of international markets. Moreover, in 2009, the Ministry of Commerce and the Ministry of Science and Technology jointly issued 'Opinions on Encouraging Technology Export' which encourages foreign collaborations and cross-border M\&As by Chinese enterprises engaged in the development of technology.

Consequent to these policy changes, in the post 2002 period, the motivation of cross-border M\&As undertaken by Chinese MNEs seems to be changing. Deng (2009) observes that an increasing number of Chinese firms are investing in developed economies by aggressive M\&A, and contends that government support is an important determinant. Chinese MNEs use M\&As in advanced countries as a springboard for acquiring strategic assets (Luo \& Tung, 2007); for instance, machinery in Germany, designs in Italy and automobiles in the UK (Nicolas \& Thomsen, 2008). UNCTAD (2005) further points out that the Chinese government actively encourages OFDI in overseas R\&D centres as a result of which China has emerged as the largest foreign investor in R\&D projects in Europe. We thus argue that strong government directions have made Chinese M\&As more sectorally and geographically diversified and hypothesise that:

Hypothesis 1a: The 'Go Global' policy has pushed Chinese cross-border MEAs into countries that have a larger pool of strategic assets. (The location choice) 
Hypothesis 1b: Chinese MNEs invest a larger volume of funds in cross-border MEAs in countries that have a larger pool of strategic assets. (The amount of investment)

Thus, our first hypothesis (1a) is that Chinese M\&As locate where they can acquire strategic assets and our second hypothesis (1b) concerns the investment amount in these M\&As.

\section{The Institutional Framework in Host Countries}

MNE's location choices are determined by the host country's economic and noneconomic attributes. The economic attributes consist of factors such as market size, and natural resources, whereas non-economic attributes consist of legal, social, and political factors. While the role of economic factors is well documented in the extant literature (see Dunning \& Lundan, 2008 for a detailed discussion), it is the social, legal and political forces that make up the institutional framework of host country that influence the EMNEs location choice in a different way from traditional MNEs. For instance, a good governance structure in a host country reduces the degree of political risk, thereby increasing its attractiveness for international business, and vice versa (Blonigen, 2005; Robock, 1971). However, in contrast, research suggests that EMNEs have experience of, and high tolerance towards political risk, which makes them different from western MNEs, and therefore political risk may not negatively affect their location choice decision (Buckley et al., 2007; Buckley, Enderwick, Forsans, \& Munjal, 2013; Munjal, 2014).

Prior research on the context of Chinese MNEs confirms that Chinese MNEs are less risk averse than their western counterparts (Kolastad \& Wigg, 2012; Li \& Liang, 2012; Quer et al., 2012). The difference in their attitude towards political risk is attributable to a number of factors. First, Chinese MNEs (especially SOEs) have fewer financial constraints on OFDI and the imperfect domestic capital market creates a specific financial advantage (Voss et al., 2008). In the context of Chinese MNEs, special institutions at home, such as the government's direction and financial support, may lead to unconventional location choices by Chinese MNEs. Large and rapidly growing domestic markets give them enough cash to invest abroad, and some Chinese SOEs often have access to cheap state finance. For instance, the China Development Bank and the China Export and Import Bank are committed to provide the best possible service to help Chinese firms to invest overseas (Buckley et al., 2007; Dohse et al., 2012; Economist, 2010; Rui \& Yip, 2008). Such privileges reduce the commercial or financial risks of OFDI, mitigate institutional distance and subsidize less profitable technology. Secondly, Chinese investors are attracted towards risky environments when strong bilateral political relations exist between China and the host country as this may reduce potential risk (Amighini et al., 2012). Third, Chinese investors are attracted to the short-term economic rents that arise in risky host countries. Moreover, Chinese MNEs' also exhibit indifference towards the institutional conditions in host countries because of their experience of operating at 


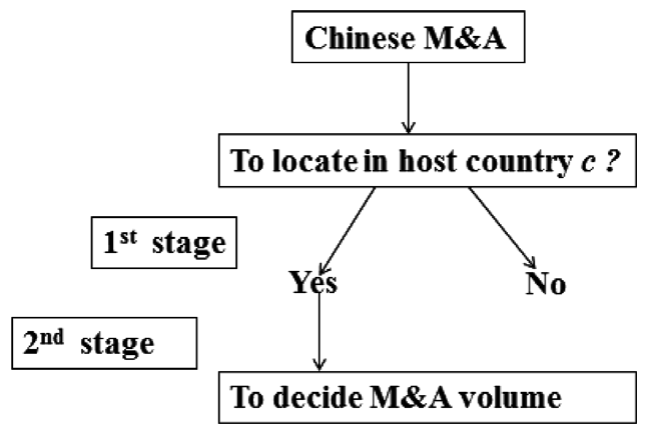

Figure 2. Logic of Heckman's two-stage model

home and in other developing countries with poor governance structures (Buckley et al., 2007; Quer et al., 2012). Therefore, we hypothesise that:

Hypothesis 2a: Chinese MEAs are not negatively associated with high levels of political risk in host countries. (The location choice)

Hypothesis 2b: Chinese MNEs undertake larger MEAs in locations that are riskier. (The amount of investment)

Thus, our third hypothesis (2a) is that Chinese M\&As locate in high risk countries and our fourth hypothesis (2b) concerns the amount invested in M\&As in high risk countries.

\section{METHODS AND MODEL SPECIFICATION}

We use Heckman's two-stage model (Helpman et al., 2008) to examine our hypotheses - 1a and $2 \mathrm{a}$ on location choice and $1 \mathrm{~b}$ and $2 \mathrm{~b}$ on investment amount. Heckman's two-stage model allows us to examine the firm's decision to undertake cross-border M\&As at two different levels as illustrated in Figure 2 and to estimate unbiased results by including countries which did not host M\&As by Chinese MNEs.

In the first stage, Chinese firms consider whether to conduct M\&A in host country $c$ or not. If yes, they will decide M\&A volume in the second stage. Suppose $y_{c t}$ represents China's real M\&A volume in host country $c$ in year $t$, and we have:

$$
y_{c t}= \begin{cases}y_{c t}^{*} & \text { if } y_{c t}^{*}>0 \\ 0 & \text { if } y_{c t}^{*} \leq 0\end{cases}
$$

In equation (1), latent variable $y_{c t}^{*}$ is given by following model:

$$
\mathrm{y}^{*}=\alpha+\beta_{1} \mathrm{I}_{\mathrm{ct}-1}+\beta_{2} \mathrm{x}_{\mathrm{ct}-1}^{\prime}+\mu_{\mathrm{ct}}
$$

Where, $\mathrm{I}_{\mathrm{ct}-1}$ represents host country's institutional quality in time $\mathrm{t}-1 ; \beta_{1}$ and $\beta_{2}$ are the usual regression coefficients, $\mathrm{x}_{\mathrm{ct}-1}$ is a vector of control variables, including traditional location factors, such as market size, natural resources, strategic assets in the host country, its trade volume with China and year (fixed effect); $\mu_{\text {ct }}$ is the error 
term that respects the normal distribution $\left(0, \sigma^{2}\right)$. In order to avoid endogeneity, we use a one-year lag of these variables. In fact, we estimate $E\left(y_{c t} \mid X_{c t-1}, y_{c t}^{*}>0\right)$, thus,

$$
\begin{aligned}
E\left(y_{c t} \mid X_{c t-1}, y_{c t}^{*}>0\right) & =X_{c t-1}^{\prime} \beta+E\left(u_{c t} \mid u_{c t}>-X^{\prime}{ }_{c t-1} \beta\right) \\
& =X^{\prime}{ }_{c t-1} \beta+\sigma\left[\frac{\phi\left(X^{\prime}{ }_{c t-1} \beta / \sigma\right)}{\Phi\left(X^{\prime}{ }_{c t-1} \beta / \sigma\right)}\right] \\
& \neq X_{c t-1}^{\prime} \beta
\end{aligned}
$$

In which $\left[\frac{\phi\left(X_{c t-1}^{\prime} \beta / \sigma\right)}{\Phi\left(X^{\prime}{ }_{c t-1} \beta / \sigma\right)}\right]$ is so-called Inverse Mill's ratio. Since $\left[\frac{\phi\left(X^{\prime}{ }_{c t-1} \beta / \sigma\right)}{\Phi\left(X^{\prime}{ }_{c t-1} \beta / \sigma\right)}\right]$ is correlated with $X_{c t-1}^{\prime}$, and if we neglect this ratio in the regression, the condition of independence assumption (CIA) will be violated and sample selection bias will happen. Therefore, we need to consider an excluded variable (ENTCOST) that exists in the first-stage equation but is not included in second-stage equation in order to avoid multi-collinearity between inverse Mill's ratio and the independent variables. Since we are mainly interested in the impacts brought about by institutional constraints, the excluded variable in our study should describe the institutional quality in the host country.

ENTCOST stands for entry cost which is measured using indicators provided in the World Bank's Doing Business report. The Doing Business reports have a comprehensive set of indicators widely used for the measurement of firms' entry costs. However, Doing Business reports have two major limitations: 1) the time series in the Doing Business reports starts from 2003, while the time span in our research is from 1985 to 2012; 2) the yearly change of the indicator in one country and the relative rank among the countries are small. In order to resolve these limitations we follow Helpman et al. (2008) by taking the average value of the Doing Business indicators from 2003 to 2011 as the entry cost for each country. We then calculated medians values for our sample of 150 countries. On this basis, we generated a dummy variable of entry costs. For countries with entry cost greater or equal to the median, the value of 1 is assigned and for countries with entry cost less than the median, the value of 0 is assigned.

Therefore, first-stage location choice specification is:

$$
\operatorname{Pr}\left(\mathrm{y}_{\mathrm{ct}}{ }^{*}>0\right)=\alpha+\beta_{1} \mathrm{I}_{\mathrm{ct}-1}+\beta_{2} \mathrm{x}_{\mathrm{ct}-1}^{\prime}+\beta_{3} E_{\mathcal{N} T C O S T_{\mathrm{ct}}}+\mu_{\mathrm{ct}}
$$

Based on equation (4), we include Inverse Mill's ratio in second-stage specification:

$$
\mathrm{y}_{\mathrm{ct}}^{*}=\alpha+\beta_{1} \mathrm{I}_{\mathrm{ct}-1}+\beta_{2} x_{\mathrm{ct}-1}^{\prime}+\beta_{4} \operatorname{Mill}_{\mathrm{ct}}+\mu_{\mathrm{ct}}
$$

\section{SAMPLE, DATA, AND VARIABLES}

\section{Sample}

Our M\&A data are taken from the Thomson Financial SDC Platinum database, and we only consider Chinese M\&A transactions which have been actually completed. 
M\&A deals during the period of 1985-2011were examined. In order to eliminate the sample selection bias, common in traditional research, in studying the location choice we include 70 countries whose transaction volumes are zero. We selected these countries on the basis of their economic and non-economic attributes, such as market size, natural resource and strategic asset endowments, so that the two groups of countries are comparable. Thus, our sample of econometric regressions contains 150 countries in a period of 27 years.

\section{Data and Variables}

Independent variables. Our main independent variable is the quality of the host countries' institutions. It was measured in two ways: 1) Government Stability and 2) Law and Order. Both factors are important for the FDI decision as these make up the basic fabric of the institutional structure of any country. The stability of the central government, the strength and impartiality of the legal system and the observance of the law in a given host country boosts the investor's confidence motivating them to first choose the location for investment and second undertake larger investment. Data for both variables are obtained from the International Country Risk Guide (ICRG) published by the PRS Group. This is a popular database which provides a comprehensive score for more than 150 countries from 1980 onwards. Higher scores indicate better institutional environment.

The definitions and statistical description of variables are summarized in Table 2.

\section{Control Variables}

We control for the standard attributes of host countries, including market size, growth rate, natural resources, and geographic distance, in order to control for heterogeneity among host countries. These are standard variables and have been included as controls in prior research. A brief description of these variables is as follows:

Market. We include three measures, namely GDP, per capita GDP (GDPP) and GDP growth rate (GDPG). GDP measures the market size (Buckley et al., 2007; 2012); per capita GDP (GDPP) is used to measure the market purchasing power (Bénassy-Quéré et. al., 2007; Yao \& Wang, 2013); and GDP growth rate (GDPG) is used to judge host countries' growth potential (Billington, 1999; Zhang \& Daly, 2011). It is an also an indicator of a country's political stability and the government's economic track record (Fan et al., 2009). GDP and per capita GDP are in logarithmic form. The data are obtained from the World Development Indicators (WDI). 
Table 2. Definitions and statistics description of variables

\begin{tabular}{|c|c|c|c|c|c|c|}
\hline VARIABLES & $\mathcal{N A M E}$ & Definition & Average & $\begin{array}{l}\text { Standard } \\
\text { Deviation }\end{array}$ & Minimum & Maximum \\
\hline Dependent & TRANV & $\begin{array}{l}\text { Transaction volume } \\
\text { of M\&A }\end{array}$ & 17.94 & 2.77 & 9.95 & 22.86 \\
\hline \multirow[t]{2}{*}{$\begin{array}{l}\text { Host formal } \\
\text { institutions }\end{array}$} & Measure 1 & $\begin{array}{l}\text { Government } \\
\text { stability }\end{array}$ & 1.98 & 0.36 & -0.41 & 2.48 \\
\hline & Measure 2 & $\begin{array}{l}\text { Legal and social } \\
\text { order }\end{array}$ & 1.20 & 0.49 & -0.88 & 1.79 \\
\hline $\begin{array}{l}\text { Host informal } \\
\text { institutions }\end{array}$ & LANG & Common language & 0.03 & 0.18 & 0.00 & 1.00 \\
\hline \multirow{9}{*}{$\begin{array}{l}\text { Control } \\
\text { variables }\end{array}$} & GDP & GDP & 10.00 & 2.08 & 4.87 & 16.52 \\
\hline & GDPP & GDP per capita & 7.83 & 1.68 & 4.16 & 11.65 \\
\hline & GDPG & GDP growth rate & 3.41 & 6.32 & -66.12 & 106.28 \\
\hline & ORE & $\begin{array}{l}\text { Ore resource } \\
\text { endowment }\end{array}$ & 5.66 & 12.49 & 0.00 & 88.81 \\
\hline & FUEL & $\begin{array}{l}\text { Oil and gas } \\
\text { resource } \\
\text { endowment }\end{array}$ & 12.04 & 24.59 & 0.00 & 99.95 \\
\hline & PATENT & Strategic assets & 0.13 & 7.15 & -6.91 & 13.13 \\
\hline & GDIS & $\begin{array}{l}\text { Geographic } \\
\text { distance }\end{array}$ & 9.00 & 0.57 & 7.02 & 9.86 \\
\hline & BORDER & Common border & 0.09 & 0.28 & 0.00 & 1.00 \\
\hline & TRADE & Trade dependence & 5.13 & 8.26 & 0.00 & 85.15 \\
\hline $\begin{array}{l}\text { Excluded } \\
\text { variables }\end{array}$ & ENTCOST & Entry cost & 0.49 & 0.50 & 0.00 & 1.00 \\
\hline
\end{tabular}

Source: arranged by the authors based on original data.

Natural resources. Following Buckley et al. (2007, 2012) and Kolstad \& Wiig (2012), we employed two measures, namely ORE and FUEL. ORE is the proportion of ore exports in the country's total exports and FUEL is the proportion of gas and oil exports in the country's total exports. These ratios estimate the degree to which natural resources are present in a particular country. The data are obtained from the World Development Indicators (WDI).

Strategic assets. Strategic assets refer to a country's assets in technology, brands, and innovative abilities. Referring to Buckley et al. (2007, 2012), we take the patents (PATENT) applied for by residents and non-residents in a country to measure the degree of a country's strategic assets. We use logarithmic forms of the number of patents applied for to normalise the data. The data are obtained from the World Development Indicators (WDI).

Trade. Research has shown that trade and FDI have a strong relationship (Blomström \& Kokko, 1997; Buckley et al., 2012; OECD, 2006; Wells, 1983). Analysing Chinese OFDI between 1984 and 2001, Buckley et al. (2007) show that Chinese MNEs have a 'FDI promoting exports' strategy. Prior research (see e.g. 
Zhou, 1996) suggests that Chinese firms often engage in international business while imitating their peers. We calculated the Trade variable by calculating the proportion of trade volume between China and particular host countries to the country's total international trade volume (Cheung et al., 2012; Holburn \& Zelner, 2010). The data for trade was obtained from the website of World Integrated Trade Solution (WITS) - a joint initiative of the World Bank and UNCTAD.

Geographic distance. FDI decisions are likely to be affected by geographic distance. Geographically closer markets decrease transaction costs and attract cross-border M\&A (Buckley \& Casson, 1981). Empirically, many Asian MNEs prefer to enter into geographically close countries. Both Matsushita and Haier's initial internationalization stage focused on Southeast Asia to build volume and international experience (Yang et al., 2009). Nevertheless, some Chinese MNEs in high-tech sectors, such as Huawei and Lenovo, enter markets that are geographically distant, in order to acquiring strategic knowledge assets. Geographic distance (GDIS) was calculated by taking the logarithm of the straight line distance from Beijing to the capital city in each target country (Buckley et al., 2007).

Common border. We additionally control for countries with shared borders (dummy variable Border = 1) with China. Chinese firms are more likely to undertake trade and investment with neighbouring countries. The data on GDIS and Border are obtained from CEPII in France.

Common language. Following most research, we also control for the cultural distance between China and host countries by considering the language. When the language is the same, dummy variable $L A \mathcal{N} G$ is coded 1 , otherwise 0 .

\section{RESULTS}

\section{Push Factors - Chinese Institutional Framework}

Our results, presented in Tables 3 and 4, show the effect of Chinese central government policy direction. As can be seen from the results, our Hypothesis la, the 'Go Global' policy has pushed Chinese cross-border M\&As into countries that have a larger pool of strategic assets, is supported. Hypothesis 1b, that Chinese MNEs invest a larger volume of funds in cross-border M\&As in countries that have larger pool of strategic assets, is not supported. We measured the effect of government direction by splitting our sample in time. Table 4 shows the results for the period from 2002 to 2011 , to capture the effect of the 'Go Global' policy. Results reveal that patents (our measure for strategic assets availability in host countries) gain significance in the post 2002 period. This indicates that the location choice of Chinese MNEs has changed. Chinese MNEs now prefer to enter into countries for strategic asset seeking, including technology and brands (Deng, 2009; Zhang et al., 
Table 3. Regression results of Heckman's two-stage (1985-2011)

\begin{tabular}{|c|c|c|c|c|}
\hline \multirow[b]{2}{*}{ Variables } & \multicolumn{2}{|c|}{$\begin{array}{c}\text { Model } 1 \text { Institution: Government } \\
\text { stability }\end{array}$} & \multicolumn{2}{|c|}{$\begin{array}{c}\text { Model } 2 \text { Institution: Legal and } \\
\text { social order }\end{array}$} \\
\hline & Location choice & MEAs scale & Location choice & MEAs scale \\
\hline \multirow[t]{2}{*}{ GDP } & $0.3555^{* * *}$ & 0.6920 & $0.3556^{* * *}$ & 0.5989 \\
\hline & $(0.0414)$ & $(0.4788)$ & $(0.0413)$ & $(0.4684)$ \\
\hline \multirow[t]{2}{*}{ GDPPC } & 0.0730 & 0.3695 & 0.0976 & $0.7679^{*}$ \\
\hline & $(0.0538)$ & $(0.3200)$ & $(0.0673)$ & $(0.4318)$ \\
\hline \multirow[t]{2}{*}{ GDPG } & -0.0025 & 0.0125 & -0.0048 & -0.0189 \\
\hline & $(0.0159)$ & $(0.0851)$ & $(0.0156)$ & $(0.0817)$ \\
\hline \multirow[t]{2}{*}{ ORE } & $0.0178^{* * *}$ & 0.0364 & $0.0184^{* * *}$ & 0.0389 \\
\hline & $(0.0039)$ & $(0.0320)$ & $(0.0039)$ & $(0.0320)$ \\
\hline \multirow[t]{2}{*}{ FUEL } & 0.0023 & $0.0301^{* *}$ & 0.0020 & $0.0290^{* *}$ \\
\hline & $(0.0023)$ & $(0.0134)$ & $(0.0023)$ & $(0.0133)$ \\
\hline \multirow[t]{2}{*}{ PATENT } & 0.0150 & 0.0074 & 0.0153 & 0.0078 \\
\hline & $(0.0107)$ & $(0.0534)$ & $(0.0106)$ & $(0.0532)$ \\
\hline \multirow[t]{2}{*}{ TRADE } & $0.0095^{* * *}$ & 0.0181 & $0.0094^{* * *}$ & 0.0182 \\
\hline & $(0.0021)$ & $(0.0174)$ & $(0.0021)$ & $(0.0170)$ \\
\hline \multirow[t]{2}{*}{ BORDER } & $0.6213^{* * *}$ & 2.0057 & $0.6422^{* * *}$ & 2.1347 \\
\hline & $(0.2219)$ & $(1.4449)$ & $(0.2268)$ & $(1.4520)$ \\
\hline \multirow[t]{2}{*}{ LANG } & $1.6724^{* * *}$ & 2.3564 & $1.6365^{* * *}$ & 1.8282 \\
\hline & $(0.2296)$ & $(2.3850)$ & $(0.2294)$ & $(2.2800)$ \\
\hline \multirow[t]{2}{*}{ GDIS } & $-0.2171^{* *}$ & 0.2796 & $-0.2373^{* *}$ & 0.0515 \\
\hline & $(0.0964)$ & (0.3969) & $(0.0981)$ & $(0.4116)$ \\
\hline \multirow[t]{2}{*}{ INSTITUTION } & -0.2587 & -2.0514 & -0.1722 & $-1.6722^{*}$ \\
\hline & $(0.2711)$ & $(1.3413)$ & (0.1988) & $(0.9697)$ \\
\hline \multirow[t]{2}{*}{ ENTCOST } & $-0.3007^{* *}$ & & $-0.3150^{* *}$ & \\
\hline & $(0.1235)$ & & $(0.1250)$ & \\
\hline \multirow[t]{2}{*}{ Lambda } & & 1.6951 & & 1.7449 \\
\hline & & $(1.8337)$ & & $(1.7719)$ \\
\hline \multirow[t]{2}{*}{ Constant } & -9.7290 & 5.353 & -10.0316 & 2.9566 \\
\hline & $(0.0000)$ & (9.1118) & $(0.0000)$ & $(9.1459)$ \\
\hline Observations & 2,768 & 2,768 & 2,765 & 2,765 \\
\hline
\end{tabular}

Notes: 1) standard error is reported in parenthesis; ${ }^{* * *},{ }^{* *}$, and ${ }^{*}$ represents respectively statistically significant level at $1 \%, 5 \%$ and $10 \%$; year dummy is integrated for controlling macro-economic impact. Below is the same.

2) In each model, the first column presents the estimation results regarding the location choice of China's cross-border M\&A, while the second column is the estimation results regarding the decision making on M\&A scale.

2011). In recent years, we have witnessed many cases of Chinese MNEs targeting firms in more advanced economies in Western Europe and the USA, for instance the acquisition of Volvo in Sweden by Geely and acquisition of IBM's personal computer business in the USA by Lenovo, which supports our findings. However, it is interesting to know that although Chinese firms show location choice preferences towards such advanced countries, their real volume of investment is not significantly affected by the endowment of strategic assets in these economies. This is probably because Chinese MNEs are still in their infancy in seeking strategic assets and therefore are not selectively targeting western firms. Thus, we argue that although 
Table 4. Regression results of Heckman's two-stage (2002-2011)

\begin{tabular}{|c|c|c|c|c|}
\hline \multirow[b]{2}{*}{ Variables } & \multicolumn{2}{|c|}{$\begin{array}{c}\text { Model } 1 \text { Institution: Government } \\
\text { stability }\end{array}$} & \multicolumn{2}{|c|}{$\begin{array}{c}\text { Model } 2 \text { Institution: Legal and } \\
\text { social order }\end{array}$} \\
\hline & Location choice & MEAs scale & Location choice & MEAAs scale \\
\hline \multirow[t]{2}{*}{ GDP } & $0.3371^{* * *}$ & $0.8845^{*}$ & $0.3318^{* * *}$ & 0.7608 \\
\hline & $(0.0500)$ & $(0.4960)$ & $(0.0497)$ & $(0.4699)$ \\
\hline \multirow[t]{2}{*}{ GDPPC } & $0.1261^{*}$ & 0.4411 & $0.2276^{* * *}$ & 1.0271 \\
\hline & $(0.0662)$ & $(0.4341)$ & $(0.0865)$ & $(0.6509)$ \\
\hline \multirow[t]{2}{*}{ GDPG } & $0.0372^{*}$ & 0.0049 & $0.0329^{*}$ & -0.0263 \\
\hline & $(0.0190)$ & $(0.1268)$ & $(0.0188)$ & $(0.1210)$ \\
\hline \multirow[t]{2}{*}{ ORE } & $0.0139^{* * *}$ & 0.0442 & $0.0162^{* * *}$ & 0.0515 \\
\hline & $(0.0049)$ & $(0.0328)$ & $(0.0050)$ & $(0.0338)$ \\
\hline \multirow[t]{2}{*}{ FUEL } & 0.0022 & $0.0342^{* *}$ & 0.0012 & $0.0315^{* *}$ \\
\hline & $(0.0027)$ & $(0.0159)$ & $(0.0027)$ & $(0.0158)$ \\
\hline \multirow[t]{2}{*}{ PATENT } & $0.0312^{* *}$ & 0.0283 & $0.0337^{* *}$ & 0.0282 \\
\hline & $(0.0137)$ & $(0.0862)$ & $(0.0138)$ & $(0.0862)$ \\
\hline \multirow[t]{2}{*}{ TRADE } & $0.0094^{* * *}$ & 0.0264 & $0.0091^{* * *}$ & 0.0267 \\
\hline & $(0.0022)$ & $(0.0197)$ & $(0.0022)$ & $(0.0188)$ \\
\hline \multirow[t]{2}{*}{ BORDER } & $0.4603^{*}$ & 2.4426 & $0.5229^{*}$ & 2.4964 \\
\hline & $(0.2676)$ & $(1.5801)$ & $(0.2740)$ & $(1.5929)$ \\
\hline \multirow[t]{2}{*}{ LANG } & $1.5686^{* * *}$ & 2.6012 & $1.3988^{* * *}$ & 1.8184 \\
\hline & $(0.3394)$ & $(2.4996)$ & $(0.3365)$ & (2.1782) \\
\hline \multirow[t]{2}{*}{ GDIS } & $-0.3782^{* * *}$ & 0.0709 & $-0.4604^{* * *}$ & -0.2842 \\
\hline & $(0.1243)$ & (0.5883) & $(0.1267)$ & $(0.6362)$ \\
\hline \multirow[t]{2}{*}{ INSTITUTION } & $-0.7866^{* *}$ & -2.9576 & $-0.6037^{* *}$ & $-2.4861^{*}$ \\
\hline & $(0.3796)$ & $(1.9021)$ & $(0.2561)$ & (1.4785) \\
\hline \multirow[t]{2}{*}{ ENTCOST } & $-0.3084^{* *}$ & & $-0.3543^{* *}$ & \\
\hline & $(0.1524)$ & & $(0.1536)$ & \\
\hline \multirow[t]{2}{*}{ Lambda } & & 2.3061 & & 2.3246 \\
\hline & & $(2.0464)$ & & $(1.9015)$ \\
\hline \multirow[t]{2}{*}{ Constant } & -1.4989 & 5.0223 & $-2.4345^{*}$ & 1.6472 \\
\hline & (1.4455) & $(7.8820)$ & (1.2852) & (8.4203) \\
\hline Observations & 1,192 & 1,192 & 1,192 & 1,192 \\
\hline
\end{tabular}

Notes: 1) standard error is reported in parenthesis; ${ }^{* * *},{ }^{* *}$, and ${ }^{*}$ represents respectively statistically significant level at $1 \%, 5 \%$ and $10 \%$; year dummy is integrated for controlling macro-economic impact. Below is the same.

2) In each model, the first column presents the estimation results regarding the location choice of China's cross-border M\&A, while the second column is the estimation results regarding the decision making on M\&A scale.

their location choice is changing, advanced countries have still not become major hub for Chinese M\&As in terms of investment volumes.

\section{Pull Factors - Institutional Framework in Host Countries}

The results reported in Table 3 show the impact of the institutional framework in host countries - which is measured in two different ways. Model 1 represents the host country's formal institutions in terms of government stability, and Model 2 shows the quality of law and order. Results in both models are consistent and therefore 
they can be seen as a robustness check. Tables 3 and 4 show that political risk in host countries does not negatively influence the location choice decisions of Chinese MNEs, supporting our Hypotheses 2a. However, there is a positive association with the scale of cross-border M\&As, meaning that Chinese firms prefer to undertake larger cross-border M\&As in countries that have a poor record of law and order (Model 2). This partly confirms our Hypothesis 2b that Chinese MNEs invest more in riskier locations. Our results did not show significance for government stability (Model 1) on the actual amount of investment, which indicates that Chinese MNEs may invest in countries where the government may not be stable. This indifference towards government stability also reflects the risk taking abilities of Chinese MNEs.

It is also important to note that post 2002 Chinese MNEs are increasingly attracted towards locations that are riskier (see Table 4). As suggested earlier, the financial support and direction from the Chinese government under the 'Go Global' policy may have influenced the unconventional location choices made by Chinese MNEs (Buckley et al., 2007; Dohse et al., 2012). This reflects a changing character of Chinese MNEs towards host country risk. We further infer that the experience of operating at home, where the institutions are underdeveloped, also gives Chinese MNEs a specific competitive advantage over western MNEs when operating in countries with underdeveloped institutions, i.e. countries with high risk (Buckley et al., 2007; Quer et al., 2012). This allows Chinese MNEs to operate in host countries such as Sudan, Iraq and Syria that do not offer high quality institutions. The perverse behaviour towards host country risk, due to the poor quality of institutions, confirms prior research which suggests that Chinese MNEs either seeks to maximise economic rent or they have mechanisms through which they reduce the impact of such risk on the firm, e.g. prior experience and the Chinese government's ties with host countries. Further, China influences many developing countries because of its high share of their inward FDI, making China a strategic partner in their growth efforts (Buckley, Enderwick, Kafouros, Forsans, Voss, \& Munjal, 2014).

Moreover, their 'risk-seeking' motive may be caused by the dominance of SOEs (Mork et al., 2008), or the low quality of governance in private firms. Chinese firms, especially SOEs, have enjoyed privileged access to cheap money, which spurs them to invest abroad (Buckley et al., 2007). Access to government finance reduces the commercial or financial risks of OFDI, mitigating institutional distance, and subsidizes less profitable technology. The ability of Chinese SOE's to derive benefits from the imperfect domestic capital market also creates a specific ownership advantage (Voss et al., 2008) which is often described as an 'unfair' capital cost advantage (Globerman \& Shapiro, 2009). Furthermore, decisions of Chinese MNEs to invest abroad are often based on the short term goals of top Chinese SOE bureaucrats. These bureaucrats are generally on a short length of tenure during which they are more interested in the execution of 'flagship' projects which can help them in their career progression and also in appropriating funds through buying firms in host countries that have poor governance structures. Thus, the short length 
of tenure of these top executives in Chinese SOEs also militates against a long run time horizon in decision making.

\section{Motives of Gross-border M\&As}

We used standard control variables to capture the major motives for undertaking FDI. The host country's GDP is significantly positive in the two-stage regressions, while the host GDP per capita only has a significantly positive effect in the scale model (see Table 3). The insignificance of the GDP growth rate indicates that China's overseas M\&As do not involve sufficient consideration for the market potential in the target country, i.e. Chinese firms do not show a long-term consideration of the host country's economic potential. This may be because the intention is to repatriate the acquired natural resources, technology and skills to China. The host country of the investment is often not the final target market. However, with the 'Go Global' Policy, the attitude of Chinese MNEs towards the economic potential of the host country is changing as all three market parameters gain significance in their location choice decisions (Table 4). However, the insignificance of these three parameters still remains in the deciding of the actual amount of investment.

In terms of natural resources, the coefficient of the $O R E$ variable is significantly positive for location choice, while those of FUEL are only significantly positive in the analysis of investment scale, in both Tables 3 and 4. We deduce that the amount of investment in extraction of natural resources is often subject to the host country's government approval and therefore Chinese MNEs will be attracted towards locations that have a large endowment of natural resources but their actual investment may not be purely based on the availability of natural resources. Conversely, whether M\&As in the gas and oil industry can be successful is subject to China's diplomatic relations with the target country; but after the M\&A agreement is made, the scale of investment is more dependent on the abundance of these resources in the host country. Thus, the destination of Chinese firms' investment is likely to be in line with the government's agenda of national economic development. Since 1992, the central government has had a clear objective to use oil and gas resources both in China and in target foreign countries in which the Chinese government establishes diplomatic ties. CNPC's acquisition in Peru, SINOPEC's M\&As in Asia, the Middle East and South America, and CNOOC's acquisition of Spanish firm Repsol's oil field in Indonesia are all examples of targeted investments. In line with some previous studies, we argue that the idiosyncrasy of China's institutional environment at home provides additional explanations for Chinese OFDI because an important part of the Chinese OFDI has been directed at countries having close political and ideological ties with China, many of which have a high political risk, but abundant natural resources (Andreff, 2013; Cui \& Jiang, 2010; Quer et al., 2012). Li and Liang (2012) suggest that the puzzle of why Chinese OFDI goes to high political risk countries is not because of their risk 
preference but because of good political relations with China, which in fact reduce risk.

In addition, the Trade coefficient is significantly positive in location choice decisions, in both tables 3 and 4, indicating that the more a country has tight trade ties with China, the greater is the probability of Chinese M\&A in that country. However, the investment scale is not dependent on the trade intensity of the host country with China. Trade ties may help Chinese acquirers better to understand potential target countries, and then to reduce information search costs. This finding is similar to the trade-based FDI pattern of South Korean firms (Hong \& Kim, 2003). Trade policy, specifically export promotion, is an important push factor for China's cross-border M\&As.

Finally, in both tables 3 and 4, a common language and a joint border both positively influence the location choice of China's M\&As but not the amount of their investments. Geographic distance, on the other hand, negatively affects the location choices of Chinese MNEs. Some previous studies using Hofstede's index or the number of immigrants from the home country to measure cultural linkages between two countries also suggest that cultural proximity affects Chinese OFDI (Bertrand et al., 2004; Buckley et al., 2007; Cui \& Jiang, 2010). However, our study reveals that it is only the location choice decisions which are affected by language, joint border, and geographic distance while the actual amount of investment is based on the motives of Chinese MNEs and the institutional setup in home and host countries.

\section{DISGUSSION}

Based on the institutional framework at home and host countries, this study applies Heckman's two-stage model to analyse empirically the location strategies of Chinese cross-border M\&As during the period 1985-2011 and across 150 economies. The results show that both institutional factors in China and in the host countries are important location determinants. In addition, different languages and non-adjacent border are investment barriers for Chinese MNEs.

The 'Go Global' policy pushed Chinese MNEs to locate increasingly in countries with abundant strategic assets. However, Chinese MNEs display a changing character when making on cross-border M\&As. Since the launch of the 'Go Global' policy, their risk indifference towards the host location is changing into risk preference. Both location choice and amount of investment of Chinese M\&As are positively affected by the poor institutional fabric of the host country, which may damage the firm's long term profitability.

\section{Theoretical Contributions}

The current study makes three contributions to IB research on Chinese OFDI. First, we construct a theoretical framework which is different from the traditional 
industry-based view and the resource-based view. By considering China's specific development stage, we mainly focus on Push-Pull institutional factors in China and in the host country. Second, we examine the M\&A mode in contrast to greenfield investments, used in previous studies. Third, we use the Heckman two-stage model to verify quantitatively our theoretical hypotheses, which examines both the location choice decision and the real volume of M\&As as two different stages in the FDI decision process.

\section{Limitations and Future Research Directions}

Further in-depth research on Chinese cross-border M\&As can be developed in two ways. First, an investigation into the firm level issues of M\&A, using more detailed firm-level data; for instance, the impact of ownership on the firm's decision to locate and its motives in conducting M\&As. Second, regional disparity is a feature of China, so institutional factors at home are likely to vary at the regional or sub-regional level, and therefore, the regional heterogeneity of institutional factors needs to be taken into account in future studies.

\section{Managerial Implications}

The study offers managerial implications. It suggests that Chinese MNEs need to avoid being 'shortsighted'. By strict and logical econometric analysis, we show that Chinese acquirers lack a long term horizon as they show risk perverse behaviour in their overseas M\&As. Some 'loophole-seeking' behaviour may distort the initial intention of the 'Go Global' policy, such as rent-seeking in high risk countries, or the irrational use of retained earnings to fund 'flagship' projects rather than investments with high economic returns. These behaviours disturb the competitive mechanism and intensify the existing imperfect capital market (for instance, illegal loans, corruption, and embezzling public funds for personal careers as bureaucrats) (Morck et al., 2008; Voss et al., 2008). Moreover, China's lack of a 'risk-protection' system, which evaluates potential investment risk in target countries, is also a hidden problem for Chinese OFDI. Therefore, financial regulations and corporate governance at the firm level need to be strengthened, and the rational design of incentive policies and a 'risk-protection' system of OFDI environment should also be implemented.

\section{NOTES}

We thank the National Science Foundation of China (Project No.71302009), National Social Science Foundation of China (Project No.13CJY052), and Fundamental Research Funds for the Central Universities in UIBE (Project No. CXTD4-02) and Wuhan University of Technology (Project No. 2015VI003) for the financial support.

This paper won the 'Best Paper Award in Emerging Economies Research' at the Academy of International Business 2015 Annual Meeting held at Bengaluru. The award was sponsored by the Bryant University, USA. 


\section{REFERENCES}

Alon, I., Child, J., Li, S., \& McIntyre, J. R. 2011. Globalization of Chinese firms: Theoretical universalism or particularism. Management and Organization Revieze, 7(2): 191-200.

Amighini, A., Rabellotti, R., \& Sanfilipo, M. 2012. Do Chinese SOEs and private companies differ in their foreign location strategies? EUI Working Paper, RSCAS working paper \# 27, European University Institute, Florence.

Andreff, W. 2013. Comparing outward foreign direct investment strategies of Russian and Chinese multinational companies: Similarities and specificities. EAEPE Conference - Beyond Deindustrialisation: The Future of Industries, Paris.

BBC. 2009. Rio Tinto scraps China firm deal. [Cited 16 August 2015.] Available from URL: http://news.bbc.co.uk/1/hi/business/8084350.stm

Bénassy-Quéré, A., Coupet, M., \& Mayer, T. 2007. Institutional determinants of foreign direct investment. The World Economy, 30(5): 764-782.

Bertrand, O., \& Madariaga, N. 2002. US greenfield investments and M\&As location: Impact of American continental integration and insider vs. outsider position. Documento de Trabajo TEAM, Université Paris I Sorbonne et GNRS.

Bertrand, O., Mucchielli, J.-L., \& Zitouna, H. 2004. Location choices of multinational firms: The case of mergers and acquisitions. Journal of Economic Integration, 22(1): 181-209.

Billington, N. 1999. The location of foreign direct investment: An empirical analysis. Applied Economics, 31(1): 65-76.

Blomström, M., \& Kokko, A. 1997. Regional integration and foreign direct investment. $\boldsymbol{C E P R}$ Discussion Papers, 1659, G.E.P.R.

Blonigen, B. A. 2005. A review of the empirical literature on FDI determinants. Atlantic Economic Journal, 22(4): 383-403.

Boateng, A., Qian, W., \& Tianle, Y. 2008. Cross-border M\&As by Chinese firms: An analysis of strategic motives and performance. Thunderbird International Business Revieze, 50(4): 259-270.

Boisot, M., \& Meyer, M.W. 2008. Which way through the open door? Reflections on the internationalization of Chinese firms. Management and Organization Revieze, 4(3): 349 365.

Bond, P. 2006. Looting Africa: The economics of exploitation. Scottsville: Zed Books.

Brautigam, D. 2009. The dragon's gift: The real story of China in Africa. Oxford: Oxford University Press.

Buckley, P. J., \& Casson, M. 1981. The optimal timing of a foreign direct investment. Economic Journal, 91(361): 75-87.

Buckley, P. J., Clegg, J., Cross, A., Zheng, P., Voss, H., \& Liu, X. 2007. The determinants of Chinese outward foreign direct investment. Journal of International Business Studies, 38(4): 499 518.

Buckley, P. J., Munjal, S., Enderwick, P., \& Forsans, N. 2016a. Cross-border acquisitions by Indian multinationals: Asset exploitation or asset augmentation? International Business Revieze, 25(4): 986-996.

Buckley, P. J., Munjal, S., Enderwick, P., \& Forsans, N. 2016b. Do foreign resources assist or impede internationalisation? Evidence from internationalisation of Indian multinational enterprises, International Business Reviez, 25(1): 130-140.

Buckley, P.J., Enderwick, P., Forsans, N., \& Munjal, S. 2013. Country linkages and firm internationalisation: Indian MNEs within economic-political alliances of nations. In G. Cook \& J. Johns (Eds.), The changing geography of international business: 79-94. Basingstoke: Palgrave MacMillan.

Buckley, P. J., Forsans, N., \& Munjal, S. 2012. Host-home country linkages and host-home country specific advantages as determinants of foreign acquisitions by Indian firms. International Business Revieze, 21(5): 878-890.

Buckley, P. J., Enderwick, P., Kafouros, M., Forsans, N., Voss, H., \& Munjal, S. 2014. Trade and economic relations with China: Perspectives from the commonzealth, A Special Report for the Secretary General of the Commonwealth, James E. Lynch India and South Asia Business Centre, University of Leeds.

Cheng, J. L. 2014. Country context in management research: Learning from John Child. Management and Organization Review, 10(3): 337-346. 
Cheng, L., \& Ma, Z. 2010 China's outward foreign direct investment. In R. C. Feenstra \& S.-J. Wei (Eds.), China's growing role in zoorld trade: 578-580. Chicago: University of Chicago Press.

Cheung, Y., \& Qian, X. 2009. Empirics of China's outward direct investment. Pacific Economic Revieze, 14(3): 312-341.

Cheung, Y., Haan, J., Qian, X., \& Yu. S. 2012. China's outward direct investment in Africa. Revieze of International Economics, 20(2): 201-220.

Child, J., \& Rodrigues, S. B. 2005. The internationalization of Chinese firms: A case for theoretical extension? Management and Organization Revieze, 1(3): 381-410.

Child, J., \& Marinova, S. 2014. The role of contextual combinations in the globalization of Chinese firms. Management and Organization Review, 10(3): 347-371.

Cuervo-Cazurra, A., Inkpen, A., Musacchio, A., \& Ramaswamy, K. 2014. Governments as owners: State-owned multinational companies. Journal of International Business Studies, 45(8): 919-942.

Cui, L., \& Jiang, F. 2010. Behind ownership decision of Chinese outward FDI: Resources and institutions. Asia Pacific Journal of Management, 27(4): 751-774.

Davis, L., \& North, D. 1971. Institutional change and American economic grozeth. Cambridge, UK: Cambridge University Press.

Deng, P. 2009. Why do Chinese firms tend to acquire strategic assets in international expansion? Journal of World Business, 44(1): 74-84.

Deng, P. 2004. Outward investment by Chinese MNCs: Motivations and implication. Business Horizons, 47(3): 8-16.

Dohse, D., Hassink, R., \& Klaerding, C. 2012. Emerging multinationals, international knowledge flows and economic geography: A research agenda. Kiel Institute for the World Economy, 1776: 1-28.

Duanmu, J.-L. 2012. Firm heterogeneity and location choice of Chinese multinational enterprises. Journal of World Business, 47(1): 64-72.

Dunning, J. H., \& Lundan, S. 2008. Institutions and the OLI paradigm of the multinational enterprise. Asia Pacific Journal of Management, 25(4): 573-593.

Economist. 2010. Chinese acquisitions: China buys up the world, and the world should stay open 779 for business. [Online]. [Cited 1 June 2013.] Available from URL: http://www.economist. com/node/17463473

Fan, J., Morck, R., \& Yeung, B. 2009. Institutions and foreign direct investment: China versus the rest of the world. World Development, 37(4): 852-865.

Gammeltoft, P., Filatotchev, I., \& Hobdari, B. 2012. Emerging multinational companies and strategic fit: A contingency framework and future research agenda. European Management Journal, 30(3): 175-188.

Globerman, S., \& Shapiro, D. 2009. Economic and strategic considerations surrounding Chinese FDI in the United States. Asia Pacific Journal of Management, 26(1): 163-183.

Heckman, J. 1979. Sample selection bias as a specification error. Econometrica, 47(1): 153-161.

Helpman, E., Melitz, M., \& Rubinstein, Y. 2008. Estimating trade flows: Trading partners and trading volumes. Quarterly Journal of Economics, 123(2): 441-487.

Hertenstein, P., Sutherland, D., \& Anderson, J. 2015. Internationalization within networks: Exploring the relationship between inward and outward FDI in China's auto components industry. Asia Pacific Journal of Management, forthcoming.

Holburn, G. L. F., \& Zelner, B. A. 2010. Political capabilities, policy risk and international investment strategy: Evidence from the global electric power generation industry. Strategic Management Journal, 31(12): 1290-1315.

Hong, S., \& Kim, S. 2003. Locational determinants of Korean manufacturing investments in the European union. Hitotsubashi Journal of Economics, 44(1): 91-103.

Hoskisson, R. E., Wright, M., Filatotchev, I., \& Peng, M. W. 2013. Emerging multinationals from midrange economies: The influence of institutions and factor markets.Journal of Management Studies, 50(7): 1295-1321.

Jackson, G., \& Deeg, R. 2008. Comparing capitalisms: Understanding institutional diversity and its implications for international business. Journal of International Business Studies, 39(4): $540-561$.

Kang, Y., \& Jiang, F. 2012. FDI location choice of Chinese multinationals in East and Southeast Asia: Traditional economic factors and institutional perspective. Journal of World Business, 47(1): 45-53. 
Kolstad, I., \& Wiig, A. 2012. What determines Chinese outward FDI.Journal of World Business, 47(1): 26-34.

Li, Q., \& Liang, G. 2012. Political relations and Chinese outbound direct investment: Evidence from firm- and dyadic-level tests. RCCPB Working Paper \#19.

Luo, Y., \& Tung, R. L. 2007. International expansion of emerging market enterprises: A springboard perspective. Journal of International Business Studies, 38(4): 481-498.

Luo, Y., Xue, Q., \& Han, B. 2010. How emerging market governments promote outward FDI: Experience from China. Journal of World Business, 45(1): 68-79.

Mata, J., \& Portugal, P. 2000. Closure and divestiture by foreign entrants: The impact of entry and post-entry strategies. Strategic Management Journal, 21(5): 549-562.

Meyer, K. E., Estrin, S., Bhaumik, S. K., \& Peng, M. W. 2009. Institutions, resources, and entry strategies in emerging economies. Strategic Management Journal, 30(1): 6180.

Morck, R., Yeung, B., \& Zhao, M. 2008. Perspectives on China's outward foreign direct investment. Journal of International Business Studies, 39(3): 337-350.

Munjal, S. 2014. Foreign acquisitions by Indian multinational enterprises: Testing and extending internationalisation frameworks. AIB Insights, 14(3): 21-23.

Nicholson, R. R., \& Salaber, J. 2013. The motives and performance of cross-border acquirers from emerging economies: Comparison between Chinese and Indian firms. International Business Review, 22(6): 963-980.

Nicolas, F., \& Thomsen, S. 2008. The rise of Chinese firms in Europe: Motives, strategies and implications. Working Paper for presentation at the Asia Pacific Economic Association Conference, Beijing, December 13-14.

Nocke, V., \& Yeaple, S. 2008. An assignment theory of foreign direct investment. Review of Economic Studies, 75(2): 529-557.

North, D. G. 1990. Institutions, institutional change, and economic performance. Cambridge, MA: Harvard University Press.

OECD. 2014. OECD science, technology and industry outlook 2014, OECD Publishing: Paris.

Pajunen, K. 2008. Institutions and inflows of foreign direct investment: A fuzzy-set analysis. Journal of International Business Studies, 39(4): 652-669.

Pei, G., \& Zheng, W. 2015. China's outbound foreign direct investment promotion system. Springer: Berlin Heidelberg.

Peng, M. W. 2002. Towards an institution-based view of business strategy. Asia Pacific Journal of Management, 19(2): 251-267.

Peng, M. W., Wang, D. Y. L., \& Jiang, Y. 2008. An institution-based view of international business strategy: A focus on emerging economies. Journal of International Business Studies, 39(5): 920-936.

Peng, M. W., Sun, S. L., Pinkham, B., \& Chen, H. 2009. The institution-based view as a third leg for a strategy tripod. Academy of Management Perspectives, 23(3): 63-81.

Quer, D., Claver, E., \& Rienda, L. 2012. Political risk, cultural distance, and outward foreign direct investment: Empirical evidence from large Chinese firms. Asia Pacific Journal of Management, 29(4): 1089-1104.

Ramaswamy, B., Yeung, M., \& Laforet, S. 2012. China's outward foreign direct investment: Location choice and firm ownership, Journal of World Business, 47(1): 17-25.

Richet, X. 2013. The internationalisation of Chinese firms: Growth, motives, strategies. In V. Delteil, P. Dieuaide \& X. Richet (Eds.), Strategies of multinational corporations and social regulations: European and Asian Perspectives: 37-54. Springer, Heidelberg.

Robock, S. 1971. Political risk: Identification and assessment. Columbia Journal of World Business, 6(4): 6.

Rui, H., \& Yip, G. 2008. Foreign acquisitions by Chinese firms: A strategic intent perspective. Journal of World Business, 43(2): 213-226.

Scott, W. R. 1995. Institutions and organizations. London: Sage.

Sun, S. L., Peng, M. W., Ren, B., \& Yan, D. 2012. A comparative ownership advantage framework for cross-border M\&As: The rise of Chinese and Indian MNEs. Journal of World Business, 47(1): 4-16.

UNCTAD. 2005. World investment report: Transitional corporation and internationalisation of $\boldsymbol{R} \& \boldsymbol{D}$. United Nations Conference on Trade and Development, New York and Geneva. 
UNCTAD. 2014. World investment report: Investing in the SDGs: An action plan. United Nations Conference on Trade and Development, New York and Geneva.

Voss, H., Buckley, P., \& Cross, A. 2008. The impact of home country institutional effects on internationalization strategy of Chinese firms. The Multinational Business Revieze, 18(3): 25-48.

Wang, D. 2011. China's overseas foreign direct investment risk: 2008-2009. South African Institute of International Affairs, Occasional Paper No. 73: 1-30.

Wang, C., Hong, J., Kafouros, M., \& Boateng, A. 2012. What drives outward FDI of Chinese firms? Testing the explanatory power of three theoretical frameworks. International Business Revieze, 21(2): 425-438.

Wells, L. Jr. 1983. Third world multinationals: The rise of foreign investment from developing countries. Cambridge: MIT Press.

Wu, F., \& Sia, Y. H. 2002. China's rising investment in Southeast Asia: Trends and outlook. Journal of Asian Business, 18(2): 41-61.

Xia, J., Ma, J., Lu, J., \& Liu, D. W. 2013. Outward foreign direct investment by emerging market firms: A resource dependence logic. Strategic Management Journal, 50(7): 1322-1346.

Yang, X., Jiang, Y., Kang, R., \& Ke, Y. 2009. A comparative analysis of the internationalization of Chinese and Japanese firms. Asia Pacific Journal of Management, 26(1): 141-162.

Yao, S., \& Wang, P. 2013. Has China displaced the outward investments of OECD countries? China Economic Revieze, 28(1): 55-71.

Zhang, J., Zhou, C., \& Ebbers, H. 2011. Completion of Chinese overseas acquisitions: Institutional perspectives and evidence. International Business Revieze, 20(2): 226-238.

Zhang, X., \& Daly, K. 2011. The determinants of China's outward foreign direct investment. Emerging Markets Revieze, 12(4): 389-398.

Zhou, Y. 1996. Inter-firm linkages, ethnic networks, and territorial agglomeration: Chinese computer firms in Los Angeles. Papers in Regional Science, 75(3): 265-291.

Peter J. Buckley (pjb@lubs.lubs.leeds.ac.uk), OBE, FBA, is Professor of International Business and Founder Director of the Centre for International Business, University of Leeds (CIBUL), UK. He is Cheung Kong Scholar Chair Professor in the University of International Business and Economics (UBIE), Beijing. He is also the Founding Director of the Business Confucius Institute at the University of Leeds. He was president of the Academy of International Business in 2002-2004.

Pei Yu (peguyvincent@hotmail.com) is Associate Professor of International Business at the School of Economics, Wuhan University of Technology, China. She obtained her PhD in economics at the University of Paris 1, Panthéon Sorbonne, France. Her main research interests include strategies of MNCs, FDI and agglomeration theory. She has published a number of articles in domestic and international mainstream journals and she also undertaken several research projects under the auspices of the National Social Science Fund.

Qing Liu (qliu1997@gmail.com), PhD, is an Associate Professor in economics at School of International Trade and Economics, University of International Business and Economics (UIBE). He obtained his $\mathrm{PhD}$ degrees from The University of Hong Kong. Professor Liu's research specializes in international trade and investment. His current research interest focuses on globalization and innovation, cross-border M\&As and FDI, entrepreneurship and globalization. His has published dozens of papers in decent journals like fournal of International Economics, The World Economy, etc. 
Surender Munjal (smu@lubs.leeds.ac.uk) is the Director of James E. Lynch India and South Asia Business Centre and Lecturer in International Business and Strategy at Leeds University Business School. He obtained his PhD from the University of Leeds. He has earned many accolades for his research and teaching, including the best paper award and Dean's award for excellence in teaching. He is editing a special issue on outsourcing in the fournal of Business Research.

Pan Tao (angelatao0531@163.com) is a lecturer in the School of International Trade and Economics, Shandong University of Finance and Economics, China. She obtained her $\mathrm{PhD}$ in economics at University of International Business and Economics, Beijing, China in 2014. Her main research interests include OFDI and Cross-border M\&As. She has published a number of articles in peerreviewed journals and participated in several research projects sponsored by the National Social Science Fund, and National Natural Science Foundation.

Manuscript received: August 29, 2015

Final version accepted: June 10, 2016

Accepted by: $\quad$ Editor-in-Chief Arie Y. Lewin 